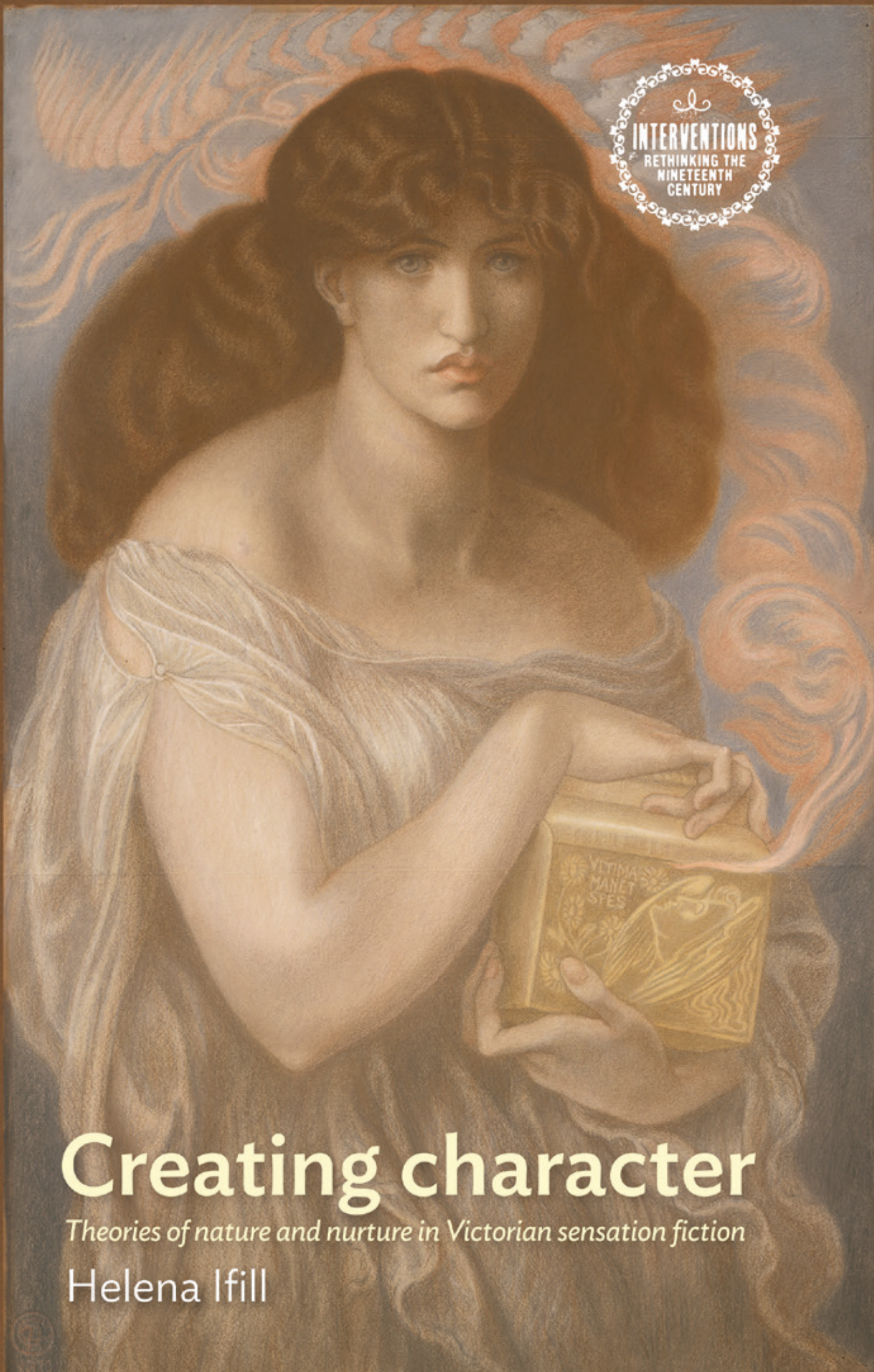




\section{Creating character}

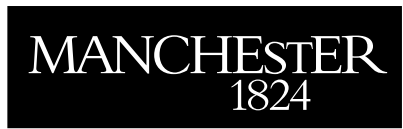

Manchester University Press 


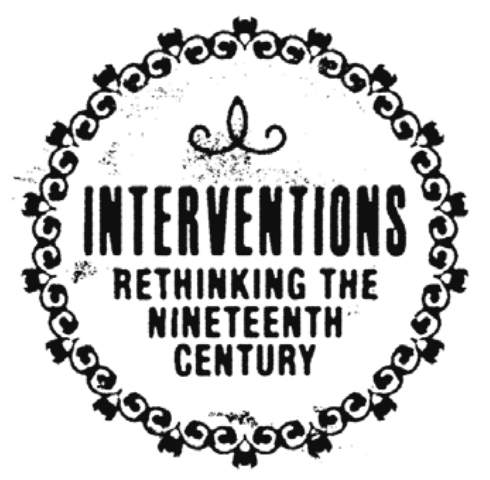

Series editors: Anna Barton, Andrew Smith

Editorial board: David Amigoni, Isobel Armstrong, Philip Holden, Jerome McGann, Joanne Wilkes, Julia M. Wright

Interventions: Rethinking the Nineteenth Century seeks to make a significant intervention into the critical narratives that dominate conventional and established understandings of nineteenth-century literature. Informed by the latest developments in criticism and theory the series provides a focus for how texts from the long nineteenth century, and more recent adaptations of them, revitalise our knowledge of and engagement with the period. It explores the radical possibilities offered by new methods, unexplored contexts and neglected authors and texts to re-map the literary-cultural landscape of the period and rigorously reimagine its geographical and historical parameters. The series includes monographs, edited collections and scholarly sourcebooks.

Already published

Charlotte Brontë: Legacies and afterlives Amber K. Regis and Deborah Wynne (eds)

The Great Exhibition, 1851: A sourcebook Jonathon Shears (ed.)

Interventions: Rethinking the nineteenth century Andrew Smith and Anna Barton (eds) 


\title{
Creating character
}

\section{Theories of nature and nurture in Victorian sensation fiction}

\author{
Helena Ifill
}

Manchester University Press 


\section{Copyright (C) Helena Ifill 2018}

The right of Helena Ifill to be identified as the author of this work has been asserted by her in accordance with the Copyright, Designs and Patents Act 1988.

Published by Manchester University Press

Altrincham Street, Manchester M1 7JA

www.manchesteruniversitypress.co.uk

British Library Cataloguing-in-Publication Data

A catalogue record for this book is available from the British Library

ISBN 9781784995133 hardback

First published 2018

The publisher has no responsibility for the persistence or accuracy of URLs for any external or third-party internet websites referred to in this book, and does not guarantee that any content on such websites is, or will remain, accurate or appropriate.

Typeset by Out of House Publishing 